\title{
IMPROVING VOCABULARY ABILITY BY USING COMIC
}

\author{
Ricky Eka Sanjaya \\ Program of English Education, Faculty of Language and Art, University of Indraprasta PGRI \\ Jalan Nangka No. 58C Tanjung Barat, Jagakarsa, Jakarta Selatan 12530 \\ sanjayaricky141@yahoo.com
}

\begin{abstract}
The aims of this research are how to improve vocabulary using comic and how to motivate the students to apply it in their English. The research is guided by a conceptual framework leading to the use of comic through peer work to improve their motivation to speak English during the process of classroom communication interaction. The research method employs an action research. The subject consists of 20 students of the first grade of SMK Al Hidayah 1 Cilandak in 2015-2016 academic year. The research data is collected by using test (test after the first treatment and test after the second treatment) and by observation for collecting data on the students' motivation in improving vocabulary ability using series pictures. Data on vocabulary ability using comic was analysed by using descriptive and statistic analysis, to know the improvement in the student's mean score after the first cycle and the second cycle. Based on the first cycle, the students' average is 67.8 , then, on the second treatment, the students' average increases to be 78.8. It can be concluded that teaching vocabulary using comic can improve students' vocabulary ability.
\end{abstract}

Key words: vocabulary ability, comic, teaching vocabulary

\begin{abstract}
ABSTRAK
Tujuan penelitian ini adalah bagaimana meningkatkan kosa kata siswa dengan menggunakan komik dan bagaimana memotivasi siswa untuk menerapkannya dalam bahasa Inggris. Penelitian ini dilaksanakan dengan konsep pemikiran menggunakan komik secara bergantian untuk memotivasi siswa berbicara dalam bahasa Inggris selama proses komunikasi yang interaktif di dalam kelas. Penelitian ini adalah penelitian tindakan. Subyek terdiri dari 20 siswa kelas X SMK Al Hidayah 1 Cilandak Tahun Pelajaran 2015-2016. Data penelitian diperoleh dari hasil tes (tes setelah tindakan ke-1 dan ke-2) dan hasil pengamatan kemampuan kosa kata siswa dengan menggunakan serangkaian gambar. Data kemampuan kosa kata dengan menggunakan komik dianalisis secara deskriptif dan statistik untuk mengetahui kemajuan rata-rata siswa setelah siklus ke-1 dan ke-2. Pada siklus ke-1 kemampuan rata-rata siswa adalah 67,8 dan setelah siklus ke-2 meningkat menjadi 78,8. Dapat disimpulkan bahwa pengajaran kosa kata dengan menggunakan komik dapat meningkatkan kemampuan kosa kata siswa.
\end{abstract}

Kata kunci: kemampuan kosa kata, komik, pengajaran kosa kata 


\section{INTRODUCTION}

Students' learning outcome, which is still considered as unsuccessful, has always been the focus of criticism towards the failure of teaching of English in Indonesia. As a consequence English teachers are demanded to be responsible for the failure in making the students capable of using English for communication both productively and receptively. To alleviate this ordeal, educators, practitioners, and policy makers quite often pay very much attention to research dealing with the curriculum, methodology and teachers excluding such significant variables as the learner's perspective. They have rarely taken the learner's perspective into consideration as a very important contribution to the learning process.

Does the failure have any relations to these factors? Some English textbooks written for young learners seem to neglect these factors. As a matter of fact, many research findings have shown the powerful role of the students in improving their learning outcome.

Teaching vocabulary in Indonesia is considered to be the most difficult, pronunciation, structure, discourse, and the social context of culture and situation. In short, it needs the mastery of the linguistic and the cultural competence. Besides, as vocabulary is difficult, more effort is required on the part of the students and teachers. It is not enough for the students to listen or to speech only. The teachers need to give the students' activities to practice the new speech among the four basic skills of language. Bourdons in Nunan (1991) stated that spoken language needs the mastery of vocabulary habit. This means that practice vocabulary needs much time to fulfil the requirements of the mastery of spoken English, either from the school or from the environment.

Teaching English at Senior High
School in Indonesia as stated in Curriculum 2004 revised in 2006 covers abilities four aspects of language. One of them is vocabulary ability. Richards and Renandya (2002) say, "Vocabulary is a core component of language proficiency and provides much of the basis how well learners speak, listen, read, and write." She further stated that if the students are able to practice the new speech habit throughout as the children do in his native language, the problem of vocabulary fluency of foreign language would be lessened.

Krashen (1989) said that students are incidentally acquiring vocabulary because of two reasons, they are familiar vocabulary and unfamiliar words. Teaching vocabulary at Senior High School in Indonesia is one of the main focus in the English teaching. Therefore the English teachers should find out the effort on searching and creating a new model in presenting materials, in order to increase vocabulary ability. Giving an assessment in the vocabulary lesson is not as easy as we imagine. Teacher should appropriately design vocabulary test. Read (2002) has divided test design into two, they are: 1) selecting a set of words which are known as unfamiliar to the test takers and then create a suitable content for each one in the form of a sentence, and 2) designing issue to select the target words and what from to present them to the test takers.

Related to the background of the research, the objective of this research is then specified to know about the effectiveness of using comic in improving their motivation to speak English through peer work and to know about the effectiveness of using comic through peer work in improving their ability to speak English as becoming good English is as a must for students. It is supported by Graddol (2006:122) who points out that "Good English is an entry 
requirement for much tertiary education in a global market where English gives the user a competitive advantage".

The result of this research is expected to be useful information to increase the teachers' knowledge of English and share experiences in improving vocabulary ability using comic; to encourage the teachers' colleagues in doing action research in improving their teaching as the professional practices; and to give any contribution to the general public in increasing knowledge concerning about classroom action research and get any reflection for being perfection.

This research is done by the subject of the students of the first grade of SMK Al Hidayah 1 Cilandak using comic through peer work to improve their ability to speak English. The researcher focused his research in improving vocabulary ability and the students' motivation in the process of teaching and learning using comic. The topics or themes used are global warming and daily activity. Comic through peer work are used to attract and to encourage the students to improve their ability to construct their understanding and the ability to speak English and also to help the teacher to present the materials.

\section{METHOD}

The method used in this research is classroom action research (CAR) focused on improving vocabulary ability using comic. The subject of the research consists of 20 students of the first grade of SMK Al Hidayah 1 Cilandak in 20152016 academic year.

This research had one dependent variable and one independent variable. The independent variable of this research is the teaching device using comic through peer work. Using comic means the pictures belong to the students (e.g. pictures taken from magazines and newspapers) or the pictures that the students had drawn by themselves. Peer work is a teaching technique or activity which allowed students to act in accordance with the assignment. Furthermore, the dependent variable of this research is vocabulary ability. It is empirically conducted by the students' mastery of using comic which covered fluency, pronunciation, vocabulary, structure, discourse and the social context of vocabulary.

To collect data, the instruments to be used are: 1) test consisted of pre-test, post-test, and formative test; and 2) observation. Test after the first treatment and test after the second treatment are administered to find out the improvement of the students' vocabulary ability, the formative test was administered to measure about the improvement of their vocabulary ability from the cycle 1 and cycle 2 . The observation is administered to measure the characteristics of the students towards the application of using comic through peer work, and questionnaire is administered to support the data of the students' improvement in vocabulary English ability.

The activities of the research used the following procedures:

1. The researcher observed the previous students' vocabulary average.

2. The researcher planned the action, constructing the lesson plan for the first cycle using comic.

3. The researcher implemented the first action cycle (giving treatment, using comic).

4. The researcher observed the classroom while implementing the actions in first cycle.

5. The researcher gave reflection to the results of the observation by 
using the guide of observation in the form of checklist.

6. The researcher analyzed the result of series picture and then classified them qualitatively.

7. The researcher constructed the lesson plan for second cycle.

8. The researcher implemented the second action cycle.

9. The researcher observed the classroom while implementing the second action cycle.

10. The researcher reflected the results of class observation in the second cycle.

11. The researcher analyzed the results of reading test in the second cycle quantitatively and then classified them qualitatively.

\section{RESULTS AND DISCUSSION}

In the first treatment, the researcher do some activities related to the using of comic. The topic chosen is global warming. The first treatment activities are:

\section{a. Warm up:}

1. Opening. This activity is as like greeting and asking students' condition.

2. Brain storming to the matter. This activity is done to guide students to the matter given.

3. Distributing the comic.

\section{b. Whilst:}

1. The teacher asks the students to guess the picture for asking the difficult vocabulary related to the picture.

2. The teacher writes the difficult vocabularies related to the picture on the board.

3. The teacher drills the difficult vocabulary related to the pictures.
4. The teacher asks them to discuss with their partners about the picture and the plot of the story.

5. The teacher asks them to tell the pictures in front one by one.

\section{c. Closing:}

1. The teacher asks their difficulty and their problem in vocabulary process.

2. The teacher gives motivation in studying and closes the lesson.

From the first treatment, the research gets the problem as bellow:

1. The pictures are not so interesting.

2. he students get difficulty in contracting the sentence, because many new vocabularies for them, so they need long time to memorize.

3. The researcher needs to pay attention more to the students who are weak in vocabulary in guiding them to make the story.

After analysing the problem above, the researcher needs to solve the problem. Hence, on the second treatment, the researcher would be easy in attempting the method. Then after choosing the interesting pictures, the researcher makes a lesson plan. Then the researcher conducts some activities in implementing the second treatment. The treatment is as follows:

\section{a. Warm up:}

1. Opening. This activity is as like greeting and asking students' condition.

2. The teacher gives brain storming to the matter. This activity is done to guide students to the matter given.

3. The teacher distributes the comic.

\section{b. Whilst:}

1. The teacher asks them to pay attention to the picture. 
2. The teacher asks the students to guess the picture and asks the difficult vocabulary related to the picture.

3. The teacher writes the difficult vocabularies related to the picture on the board.

4. The teacher drills the difficult vocabulary related to the pictures.

5. The teacher asks them to discuss with their partners.

6. The teacher asks them to present their story in their group first.

7. The teacher asks each group to give correction and suggestion to their friend's error.

8. After the correction, the teacher asks every student to tell the pictures in front.

9. The teacher asks another friend to give suggestion and correction

\section{c. Closing:}

1. The teacher asks their difficulty and their problem in vocabulary process.

2. The teacher gives motivation in studying and closes the lesson.

Based on those activities, the problems on the first treatment could be eliminated. Here, the researcher gives more assistance and support to the weak students. Besides that, the correction and suggestion from their partner in peer work could eliminate the error when they deliver their story in front. The topic about daily activity and the picture chose are so interesting and make them enthusiastic to deliver their story.

Before the treatment, the students' mean score in vocabulary is 65.0 . Then, after the treatments, data on the students' vocabulary skills are collected in line with the instruments (tests, questionnaires, and observation) and are analyzed using the scoring system, tabulating, percentage, classification, calculating the mean score, from the first treatment, the researcher gets the mean score of the students reached 67.8 and from the second treatment, the researcher gets the mean score of the students reached 78.8 .

\section{CONCLUSION}

Based on the findings and discussion in the previous parts, the conclusions are as the followings:

1. The implementation of teaching English in this action research using comic through peer work as teaching strategy could improve the students' motivation in improving their ability to speak English at both the first cycle and second cycle. It can be shown from the students' increasing average in vocabulary score. In the first treatment, the students' average is 67.8 , then, on the second treatment, the students' average increases to be 78.8 .

2. The use of comic through peer work as teaching strategy could improve vocabulary ability significantly. This leads to the conclusion that the use of comic through peer work as a teaching strategy is a need in English language teaching and learning in improving their ability to speak English in the term of vocabulary, grammar, and their performance based on the context of situation.

\section{REFERENCES}

Graddol, D. (2006). English Next. The British Council.

Krashen, S. (1989). We acquire vocabulary and spelling by reading: additional evidence for the input hypothesis. Modern Language Journal, 73(4), 440464.

Nunan, D. P. (1991). Learning Teaching Methodology: A Textbook for 
Teacher. New York: Prentice Hall.

Read, J. (2002). Assessing Vocabulary. UK: Cambridge University Press.
Richards, J. C., \& Renandya, W. A. (2002). Methodology Language Teaching: An Anthology of Current Practice. New York: Cambridge University Press. 